\title{
PENSION REFORM IN THE CZECH REPUBLIC - A CONTRIBUTION INTO THE DEBATE*
}

\author{
Marek Loužek**
}

\begin{abstract}
:
The paper is concerned with pension reform in the Czech Republic and abroad. It argues against two opinions: on the one hand, it is not necessary to do anything, and on the other hand, that a mandatory funded system should be implemented. Both approaches are false because of creating overwhelming explicit debts. The author recommends an evolutionary approach based on decreasing PAYG in combination with voluntary savings.
\end{abstract}

Keywords: pension reform, social security insurance, endogenous fertility, transition, Ricardo-Barro hypothesis

JEL Classification: J26, D02, D91, H62

\section{Introduction}

The current debate about the pension system is taking place between two extremes: on the one side, there is a relativist approach according to which it is enough to make merely cosmetic changes to the pension system. On the other side, there are radical proposals for privatisation of the pension system based on mandatory pension funds. The purpose of this paper is to offer an alternative model of pension system reform, which is more meaningful as well as more politically feasible.

The pay-as-you-go pension financing system has sunk into a crisis in the last years. The critics complain that the PAYG system is too rigid and that, as an achievement of a welfare state, it contributes to high unemployment, and that the pension insurance weakens the stimuli to work and decreases the growth potential of the economy (Schneider, 1998). The pay-as-you-go system is an institution, which may distribute the cake more equally but limits the size of this cake.

Economists had not always held such a negative opinion. During the 1950s, most people who experienced two world wars and the Great Depression believed that the PAYG system is useful and correct (Breyer, 1989). In a situation when the growth of wages and population exceeded the yield in the capital market, it seemed that the deci-

* The paper has been published with the support of a grant GA ČR no. 402/07/0165. I thank Vladimír Bezděk from the Czech National Bank, Petr Mach from the Centre for Economics and Politics, Tomáš Řezníček from ING ČR and three anonymous reviewers of "Politická ekonomie" for valuable comments. Any errors are naturally my own.

** Center for Economics and Politics and University of Economics, Prague (louzek@post.cz) 
sion to implement the PAYG system was not bad after World War II, even if the current population trend could have been predicted.

For some time now, the solution to the pension system crisis resulting from unfavourable demographic trends has been sought by governments in savings, especially in making the eligibility for pensions more stringent and sometimes even in decreasing the pension benefits (Klimentová, 1998). However, the implementation of these measures is politically and socially sensitive. In spite of that, it seems that cosmetic changes to the existing system in a number of countries are not sufficient. It is true that such changes will slow down the growth of pension expenses but they need not represent a viable solution in the long run.

The debate about the pension reform is a classical example of how economic theory of politics works (Buchanan, 1983). Political parties compete in presenting proposals for a change of the current system, which is generally regarded as unsatisfactory. However, when it comes to crunch time and details should be negotiated, it usually becomes apparent that the differences between political parties are too great to make it possible to reach a meaningful consensus.

Browning (1975) showed that in the model of government-administrated pension insurance, the disbursed pensions are not socially effective but that they are the result of the election process where the older generation outvotes the young generation. If a referendum on introduction of mandatory pension insurance were held, the older generation would probably opt for introduction of the pay-as-you-go system, even without what is known as "Aaron's condition" being met.

However, these pressures within political systems tend to result in minor, cosmetic changes to the existing system. Naturally, various political opinions are reflected in the design of the pension reform including the question of how much a state should intervene in the lives of citizens. In spite of that, it is not possible to neglect the purely economic laws according to which the pension system works (Holman, 2002).

The pension system is not suspended in mid-air; it is based on a number of wider social factors - the national tradition and historical development, experience and attitudes of the living generations, the economic standard and international context including the ratified international treaties and the Czech Republic's membership of the EU. Consequently, its reform should also take into account the social context and should have a political support.

Regrettably, there are indications that the population's political preferences concerning the type of pension system will not change very much in the near future. On the one hand, the population trend brings the pay-as-you-go system to the brink of an abyss so alternative ways of providing financial security at an old age are searched for. On the other hand, the higher portion of older persons in the population moves the age of the "median voter" towards the interests of voters in post-productive age, which prevents the implementation of a radical reform of the pension system.

The purpose of this paper is to offer a model of a pension system reform, which rejects two extremes: on the one hand, the idea that "nothing" needs to be done; and on the other hand, the idea that too much needs to be done (mandatory funds). Even though the defenders of Bismarck's system as well as the supporters of the new pension orthodoxy stand in political opposition to each other, they have one thing in common: they intend to solve the pension problem by means of indebtedness. The result of both above-mentioned approaches is a huge transitive debt. 


\section{Choice between the PAYG and Funded Systems}

The choice between the PAYG and funded systems is not a simple issue. In this part, we will analyse the standard Aaron's rule for implementation of either the PAYG system or the funded system. We will analyse the mechanism of the PAYG system and we will take a look at the strengths and weaknesses of the PAYG and funded systems. We will also mention the discussed impact of the two pension systems on savings.

\subsection{Aaron's Rule}

The starting point for the discussion about the choice of the pension system is what is known as the "Aaron's rule" (Aaron 1966):

$$
\mathrm{m}+\mathrm{g}>\mathrm{r},
$$

where $r$ is the rate of return on the private pension funds in the capital market on the right side of the inequation and where, on the left side, there is the rate of return in the PAYG system, which is determined by the population growth $(\mathrm{m})$ and the average wage growth rate $(\mathrm{g})$.

If the rate of return on the private pension funds is higher than the population growth and the average wage growth rate, then the fund-based system should be more advantageous. If, on the contrary, the population growth (the Samuelson's "biological rate of return") and the average wage (from which the pension insurance is paid) grows faster than the rate of return on the private funds, then the PAYG system for financing pensions is more advantageous.

The real rates of return on the private pension funds vary around the world. The example of Chile, where annual rates of return exceeded $12 \%$ in 1980 s is rather an exception. The estimates based on macroeconomic data and the known distribution of assets in the portfolios of Swiss pension funds show that the average annual rate of return reached $1.5 \%$ in $1970 \mathrm{~s}$ and $1980 \mathrm{~s}$ (Vittas, 1998). Thus, the real rate of return lagged behind by the real growth of wages by $1.7 \%$.

Also, the system of pension savings in Singapore was achieving relatively low rates of return in the period from 1960 s to 1990 s - around $2 \%$ per annum. With regard to the fact that the growth of real wages was exceeding $4 \%$, it seems that the real interest rate did not guarantee a very high rate of return on the investment into pension funds. In Malaysia, the annual rate of return amounted to $1 \%$. Therefore, the rate of return on the portfolio of American shares and bonds, which was generating 5.5\% in the years 1926-1992, needs to be taken with a pinch of salt.

In addition to that, it applies that if funds are mandatory, the government must strongly regulate the pension fund sector in order to guarantee the minimum pensions from these funds. High level of regulation and investments into safe instruments (most often into governmental bonds) do not result in very high rates of return. One of the drawbacks of the funded system is the limited possibility to convert the savings into some other form of savings without penalisation before reaching the age of retirement (see Slavík 2006).

Even if the Aaron's condition were met, this still does not give complete and final answer to the question regarding the efficiency of the method of financing pensions or, 
speaking more precisely, to the question of whether and under what circumstances the inter-generation Pareto-efficient allocation of consumption is achieved better by this or that method. Aaron assumed exogenous wages and interest rate, so the result rather tends to be true for a small open economy.

What is more serious is that the possibility of achieving a Pareto improvement does not take into account the mixed systems (consisting partly of PAYG system and partly of funds) or the changing level of pension contributions. Aaron's analysis was focused on examining the steady states but did not take into account the transaction costs of the entire transition and the distribution conflicts between generations. The pension systems are no longer based on single pillars because people draw pension benefits from various sources.

As Breyer (1992) correctly argues, during a transition from the PAYG system to the funded system based on private savings, it is generally impossible to compensate the first generation of pensioners for the loss, which they suffer as a result of abandoning the PAYG system, without some other generation being worse off. The choice between the various systems for financing pensions cannot be made only according to the efficiency criterion but it is also necessary to take into account the distribution among generations.

The analytical finding that if there is an unfavourable demographic trend, there is no kind of "painless" pension reform, which would result in all groups being better off, is extraordinarily significant. For example, Zbořil and Kubalč́́k (2000) promise that the young and middle-aged generations can be better off, without the older generation being worse off, if a suitable reform is implemented. This is misleading. The conflict between generations cannot be eliminated by any kind of a brilliant pension reform.

\subsection{The Workings of the Pay-As-You-Go System}

The balance of the pay-as-you-go system is determined by the following equation:

$$
\mathrm{s} \mathrm{W} \mathrm{N}=\mathrm{p} \mathrm{D},
$$

where $\mathrm{s}$ is the contribution rate; $\mathrm{w}$ is the average wage; $\mathrm{N}$ is the number of working people; $\mathrm{p}$ is the average pension and $\mathrm{D}$ is the number of pensioners. A pay-as-you-go system can always be balanced by a combination of these parameters. If there is an unfavourable demographic trend, it is possible to decrease the average pension/wage ratio, to increase the pension insurance rate or to decrease the number of pensioners - for example, by increasing the age of retirement.

PAYG is based on solidarity or on equivalence. If it is a PAYG defined benefits system, it is based on solidarity. If it is a defined contribution system, it is based on equivalence. The entitlement to pension is then based on the participation in the pension insurance, the amount of earnings and the number of years spent at work, with the insurance premium being paid from the earnings up to an earnings limit. Sometimes, a pension system is a combination of these approaches.

In spite of the fact that the PAYG systems are constructed with the purpose of ensuring social solidarity of the richer ones with the poorer ones, redistribution among generations from the rich to the poor is not so strong, if any, because there is a positive correlation between the amount of earnings made in the entire life and the life span of an 
individual (Mitchell - Zeldes, 1996). Thus, their effect can even be regressive instead of being progressive.

Both the PAYG systems and funded systems are sensitive to various types of risks. The PAYG systems are more sensitive to the demographic trend because sooner or later, they are modified to reduce the deficits of the pension systems. The funded systems are more susceptible to the risk of the capital market: various pension funds achieve various rates of return; some may even go bankrupt and the government will probably play the role of the lender of last resort.

One cannot completely agree with the opinion of Bezděk (2000) that the PAYG system is more susceptible to a political risk than the funded systems. The government or parliament can quickly change the conditions for pension insurance or savings scheme. It cannot be ruled out that after transition to a funded system, a future left-wing government, who will rise to power, will challenge the privatisation of the pension system and will impose a new tax on the middle-aged generation.

Rutarová and Slavík (2005) argue that the growing amount of such accumulated savings and the limited ability of the owners to dispose of them will motivate the state to decide to tax these resources one day (similarly like it has already happened with the goods with low elasticity of demand - indirect taxes on alcohol, petrol and tobacco products). The possibility of an individual to avoid such a tax will probably be very limited.

The inclination to the PAYG system or the funded system is linked to historical experience. In the United States, where they have enforceable laws and where capital markets work, the fact that the population favour fund-based financing can be more natural. In Central Europe, which has its own direct experience with war, monetary reforms or changes of political regimes, the higher trust in the PAYG system might not be quite incomprehensible.

One can agree with Vittas (1998) that there is no miraculous pension system. Whether it is a funded system or a PAYG system, a private system or a public one, a defined-contribution system or a defined-benefit system - none of them is able to avoid the problems of free riding, moral hazard and transaction costs. These problems affect all types of contracts and they are especially grave in the case of the pension contracts covering 60 and more years.

\subsection{Impact of the Two Systems on Savings}

The increasing age of population has its macroeconomic consequences - the level of savings, the capital reserves and growth decrease and the labour market is influenced negatively. These negative consequences occur both in the PAYG system and in the funded system. One can agree with Holman (2002) that the economic burden resulting from demographic ageing is largely independent of the form of the pension system.

Although stimulation of savings should be the advantage of the funded system, the reality can be less favourable. Most defenders of the funded system stress that this system has considerably increased the level of savings, for example, in Chile (Schmidt-Hebbel 1998). However, this is not quite clear because the increase of private savings in pension funds is offset by the decrease of other voluntary private savings. 
The impact of the social security insurance on savings is debatable. Feldstein (1974) argued that the social security insurance weakens private savings and has a negative impact on economic growth. On the contrary, he claims that the funded system contributes to increasing the level of savings and thus accelerates the economic growth. According to Feldstein, depositing savings in funds should be mandatory because some people are not responsible enough and will not save for their pensions and will then have to rely on the welfare services.

On the contrary, Barro (1978) presented a hypothesis that in a dynastic model of family with inter-generation transfers, the effect of social security insurance on savings will be neutral. The optimising players will compensate the government policy. In the future, the governmental debt will be redeemed by higher taxes. The mandatory governmental pension system does not create any new social "wealth"; it only displaces voluntary private savings.

Barro tends to be right in writing that the privatisation of a governmental pension system - if it is financed by an increase of the governmental debt - does not, as such, have any effect on national savings: the increase of private savings (in the mandatory pension funds) is fully offset by the decrease in public savings. The national savings could increase only if the reform were at least partly financed by governmental financial consolidation.

If the pension system reform increases the national savings, this is not caused by a change in the financing method (the PAYG system versus the funded system) but by the implemented budget consolidation. Although funds replace the previous mandatory PAYG system, people perceive mandatory pension funds as a substitute for voluntary savings. Therefore, the impact of introduction of a funded system on the savings may not be positive.

\section{Transition Costs}

In a number of developed countries, the governmental pension expenses hover between 10 and $15 \%$ of GDP. Since the transition costs are not zero, it is not quite easy to use the Aaron's rule for choosing between the PAYG system and the funded system. The opinion of Bulír (1998) that the funded system will "pay off" over the period of one generation and that, in addition to that, the development of the financial and capital market will bring positive externalities stimulating savings is too optimistic.

The supporters of the transition to the funded system - for example, Kreidl (1998) or Schneider (1998) in the Czech Republic - underrate the transition costs, which arise in connection with a radical pension reform. Among the members of the young generation, who would enter the new system, and the generation of the older people, who would still remain in the PAYG system, there is what is referred to as the "lost generation", who would pay twice: for their own pensions and for the pensions of their parents.

The authors suggest solving the burden on this "lost generation" by issuing bonds referred to as recognition bonds that would finance the entire reform. However, there is the problem of who and when would repay this debt. According to the Ricardo-Barro equivalence theorem (Barro, 1974), the governmental debts will be - sooner or later redeemed by higher taxes. Therefore the belief that the "lost generation" could increase their wealth during their life cycle is illusionary. 
Let us assume that the costs of the transition will be financed by the issue of recognition bonds in the amount of $\mathrm{D}$, they will increase the existing governmental debt. The resources, which the government will borrow to finance the transition, will be invested and transformed into savings in private pension funds. At the moment of the implementation of the pension "reform", the newly accumulated capital is thus precisely equal to the newly arisen debt $\mathrm{D}$ :

$$
\mathrm{D}=\mathrm{S}
$$

If an interest rate is applied, then after $n$ years, the debt would grow to $D(1+i)^{n}$, while the value of the savings would increase to $\mathrm{S}(1+\mathrm{i})^{\mathrm{n}}$. If the interest rate on bonds were equal to the annual rate of increase in the value of the assets in the private pension funds, the following would still be true:

$$
\mathrm{D}(1+\mathrm{i})^{\mathrm{n}}=\mathrm{S}(1+\mathrm{i})^{\mathrm{n}}
$$

Therefore the idea that the issue of recognition bonds could increase the overall wealth is illusionary. The objection can be raised that the interest rate on the governmental debts i may not be equal to the annual increase of the value of the assets in the pension funds $\mathrm{j}$. Optimists would say that $\mathrm{j}$ will be higher than $\mathrm{i}$, i.e. that the annual increase of the value of the assets in the funds will be higher than the interest rate on the debt. In fact, such an assumption may not be true.

The vast amount of free capital, which is accumulated in pension funds, can decrease the interest rate (see Kubíček, 2004). An increase of the governmental deficits above an acceptable level would disconcert the financial markets, which would demand higher yield for investing into the recognition bonds. Even though it is not clear in advance, which of these situations will occur, it is quite well possible that the average interest rate on the debt and the annual increase of value will offset each other.

One can agree with Vostatek (1998) that the funded system reminds a little of perpetuum mobile. If we have capital, we can have return on the capital. However, in order to obtain it, we must first accumulate savings. Therefore either we can maintain relative pensions in the future and then we have to save more (and consume less) today or we will consume today to the same extent as the previous generations and then we have to put up with lower pensions.

Therefore the statement of Kreidl (1998) that a system with a higher weight of fund financing could bring higher pensions with the same levies is not credible. This statement is only based on the static comparison of the pensions from accumulated pensions with the pensions from the PAYG system and it completely ignores that people will have to pay for the recognition bonds by suffering higher taxes (which would reduce the common consumption) or higher inflation (which will reduce the value of savings).

The calculations of the implicit debt and its comparison with the explicit debt are rather misleading. Firstly, it is necessary to realise that the implicit debt is a fictitious one, i.e. it is calculated as a hypothetical debt, which would arise, if the parameters of the PAYG system did not change. However, the parameters will change over time. Secondly, a radical pension reform carried out with the help of recognition bonds is even worse because this will change the implicit debt into an explicit one.

The estimated costs of transition to a funded system are enormous. If the current pensioners are to receive the same old-age pension as today and if the middle-aged 
generation is to obtain at least a part of their pensions from the PAYG system, the transition costs hover between one half to a double of GDP (Jelínek, Schneider, 1997). Although the authors soothingly say that the implicit debt in the PAYG system is even higher, that debt is actually fictitious, while their debt is real.

One can agree with Kreidl (1998) that mechanical preservation of the PAYG system by means of higher taxes completely ignores the effects on the entire economy - tax evasions, unemployment and distortion in the labour market. The result would be that the growth of GDP and wages would be slowed down or stopped. However, his solution to the pension reform using recognition bonds is the more surprising because these bonds would have virtually the same effect because they would have to be redeemed one day.

Whether someone likes it or not, the current young and middle-aged generations cannot disclaim their responsibility for the pension reform. Either they will pay for it through higher taxes today or through higher taxes in the future. The idea that they can get rid of their responsibility or even attain higher pensions is unrealistic. In principle, no pension system reform can solve this basic problem of inter-generation conflict.

Therefore it is difficult to agree with the opinion of Holzmann (1997) that the objective of the pension reform is to carry out a Pareto improvement. A Pareto-efficient change would occur in a situation, in which at least one group could be better off, without no other group being worse off. But this can hardly be achieved due to unfavourable demographic trend, as a result of which all generations will unavoidably be relatively worse off.

Bezděk (2001) is right in saying that the economical measures in the pension system lead to deterioration of the standard of living of the future pensioners in comparison with the current situation. If the today's middle-aged and young generation want to maintain their standard of living at an older age, they will have to limit their consumption today. If people optimise their consumption in two periods (the productive one and the post-productive one), this will not increase their overall wealth.

Of course, this does not rule out the possibility that specific individuals, who are sufficiently prudent and will save sufficient amount of finances for their pensions, will enjoy, after retirement, the same or even relatively higher pensions than those of their parents. However, on the whole, every generation will have to sacrifice something due to the current crisis of the pension system - they will consume less during the productive period or during retirement. There is no free lunch.

One can agree with the opinion of Schneider (1998) that the ageing of the population will have a negative impact on the economic growth in the following twenty years and that the investments and real wages will be decreasing as a result of taxes necessary for financing pensions. However, his estimate of increase of the economic potential by $0.5 \%$ of GDP thanks to the funded system tends to be rather speculative. Even if the funded system were introduced, the economy would bear the costs of demographic ageing.

Therefore the statement of Kotlikoff (1996) on the positive impact of the privatisation of the pension system on the economic growth is disputable. If the reform were accompanied by budget consolidation, he might be right in the long term. However, increase of the indebtedness resulting from the reform will have an opposite effect. The much too short time series do not make it possible to clearly prove the correlation between a pension reform and economic growth.

Although Gramm (1998) also supports privatisation of the pension system, his proposal for the reform is more realistic than the Kotlikoff's one. He does not borrow 
anything for the transition but introduces a special rate for savings and leaves the social security insurance rate in the USA unchanged beyond the year 2060. Thus, he does not pretend that the young and middle-aged generation will keep their standard of living but approaches the reform more transparently and responsibly.

\section{Pension Reform in the Czech Republic}

In the forth section, we will outline the basic model of pension reform in the Czech Republic, as follows from the preceding analysis. We will outline the basic philosophy as well as the specific implementation, which prefers an evolutionary approach rather than a revolutionary one. We base the model on the basic parameters of the new pension system, which are based on the calculations of Bezděk (2000) updated during the work of the task force for pension reform.

\subsection{Basic Philosophy}

One can obtain financial security for the old age in three ways. Firstly, one can postpone the present consumption and can create private savings (financial deposits, equity shares, bonds and private pensions). Secondly, one can obtain financial security for the old age by begetting and raising responsible children (Loužek, 2004). When children are young, parents provide them with food, clothes and education. When children grow up, they return the gifts to their parents in the form of financial or material transfers. Thirdly, one can participate in the social security insurance programme.

It is erroneous when the debate on financial security at an old age constantly concentrates merely on the third part. In a free society, this part should not be the dominant, let alone the only source of financial security at an old age. During the following decades, state pensions will be decreasing in all countries, which experience an unfavourable demographic trend. This finding is valid regardless of the type of a pension reform, which a country undergoes.

Through the transition process in the first half of 1990s, a pension system based on two pillars was created: the mandatory pension insurance system, in which the principle of social solidarity is applied and which is financed on the pay-as-you-go basis; and a voluntary supplementary pension insurance with a state contribution, which is designed as an individual savings scheme and which is based on capital financing.

In recent years, a task force was formed at the Czech Ministry of Finance, that calculated the pension system balance according to the alternatives presented by political parties. The opinion that the pension system needs to be reformed has prevailed among the democratic political parties. However, the proposals of individual parties vary. While the Civic Democratic Party presented a concept of equal pensions (flat state pension), the Czech Social Democratic Party recommends the Swedish model with fictitious accounts.

The Swedish model with fictitious accounts, which links the disbursed pensions more strongly to the paid contributions, is rather a cosmetic change. Although this change is a move towards a more targeted nature of the system, there is the question why people should pay their contributions to the PAYG system and not directly to private funds. The 
PAYG system should ensure solidarity; a voluntary savings scheme should, conversely, take into account the incomes and performance of the payer (see Mach, 2005).

Many authors call for privatisation of the pension system. However, it is necessary to decide whether we should privatise it completely or partly. Complete privatisation, which would mean the loss of any subsistence minimum guaranteed by the state, is hardly imaginable. It is not probable that people in Central Europe or in the West would be willing to make such a radical change of thinking. Therefore, gradual privatisation seems to be an option in the Czech Republic of the present times.

Reducing the dependence of citizens on the state, which was excessive in the past and still is, remains to be the idea behind the reform. The role of the state has changed in comparison with the previous regime and needs to be defined more precisely. It is necessary to create opportunities for people to address their welfare problems, situations and events with their own forces and activities. On the other hand, the state should intervene in those cases where a citizens cannot cope with their situation with their own forces or with the forces of their family.

For a longer time, most OECD countries have had a two-pillar pension system, which consists of the governmental PAYG system and private, voluntary pension plans. Private pension funds have a long tradition in most OECD countries, but they operate on a strictly voluntary basis. Recommendations of the World Bank concerning a three-pillar system are disputable. Thus, a combination of a state pension and a private savings scheme remains to be the model.

The idea that people should diversify their pension portfolios in order not to rely solely on the state pillar is correct. However, one cannot agree with the opinion that contribution of savings to pension funds should be mandatory. The state should guarantee financial security at an old age to the degree to which this is a public interest. To the degree to which this is a private interest, every individual must take care of this on their own. However, mandatory contributions to private pension funds are philosophically inconsistent.

\subsection{Evolutionary Concept}

Implementation of a pension revolution is only meaningful if there has been a change in the social-political factors influencing the pension system. Since we do not expect such a strong change in the preferences of the majority of the Czech Republic's population, we offer a gradual and not radical transformation of the pension system. Such a proposal is not meaningful only from economic point of view but it is even more politically viable.

It is premature to reject the PAYG system. The PAYG systems are sensitive to changes of parameters - the pension/wage ratio, the pension insurance rate and the age of retirement. One can agree with Chand and Jaeger (1996) that even the most desperate cases can be balanced through a combination of changes in the parameters of the PAYG system. The Czech Republic should take advantage of a unique opportunity and should be gradually decreasing the state pension/wage ratio over the period of a decade. 
Table

Trend in the State Pension/Average Wage Ratio

\begin{tabular}{|c|c|c|}
\hline Year & Average pensions (CZK) & Percentage of gross wage (\%) \\
\hline 1993 & 3,013 & 47.0 \\
\hline 1994 & 3,013 & 44.4 \\
\hline 1995 & 3,767 & 43.8 \\
\hline 1996 & 4,592 & 43.5 \\
\hline 1997 & 5,131 & 45.3 \\
\hline 1998 & 5,559 & 45.9 \\
\hline 2000 & 5,894 & 45.2 \\
\hline 2001 & 6,277 & 44.2 \\
\hline 2002 & 6,793 & 43.4 \\
\hline 2003 & 6,819 & 43.5 \\
\hline 2004 & 7,062 & 42.1 \\
\hline 2005 & 7,227 & 39.9 \\
\hline 2006 & 7,693 & 40.7 \\
\hline
\end{tabular}

Source: The Ministry of Labour and Social Affairs, the budget outlook

The table shows that gradual decrease of the state pension/average wage has been a real process for more then fifteen years. Thus, it should be no tragedy if this ratio continued to decrease down to $30 \%$ in 2030 or $20 \%$ in 2050 . This gradual decrease of the weight of the PAYG system can be ensured by indexing pensions according to prices and not according to the trend in nominal wages (see Holman, 2002).

Increasing pensions according to prices is not tragedy. Full wage indexation can be found virtually nowhere around the world. In practice, pensions are increased according to prices or according to a combination of prices and wages. This passive approach can relieve the Czech pension system of much of the burden. At the same time, it is necessary to encourage citizens to accumulate savings for an old age. Citizens should know that if they do not save for an old age, their standard of living will only be at the level of the subsistence minimum.

This evolutionary and not revolutionary solution to the pension system crisis is a compromise between two extremes: doing nothing and sinking into ever deeper deficits; or carrying out a radical reform with the same consequence. If no radical change in the political preferences of the population occurs in the short and medium terms (which is not probable), it is possible to reach at least a consensus on the following compromise: to keep changing the parameters of the PAYG system with the purpose of gradually decreasing its significance for the financial security at an old age.

Of course, it is necessary to continue to seek opportunities for economies within the existing system. For example, the concurrence of pensions and income from work is a problematic issue. Cancellation of widow's and widower's pensions, which seem to be obsolete in the present times - especially due to the fact that the surviving partner inherits the private pension savings of the other partner - is worth considering. More than $30 \%$ of pension benefits come from other areas than old-age pension. It is necessary to limit early retirements.

It is necessary to continue to increase the age limit for men and women up to 65 years and perhaps to an even higher age even after the year 2007. When the American pension 
system sunk into a crisis in 1970s, the government increased the age of retirement from 65 to 67 years. Today, there are proposals in the USA to change the age of retirement to up to 70 years. In the Czech Republic, too, the lifespan constantly increases, which indicates that people at an older age are healthier and perform better than in the past.

The contribution to the social security insurance would remain at the present level (but without additional debts coming into being). If the PAYG system were being balanced by increasing the pension insurance rate, this would contribute to higher unemployment. Further increase of the pension insurance rate would weaken the stimuli for investments, would bring about distortions in the labour market and would slow down the economic growth.

However, on the other hand, our proposal does not involve further decrease of the contributions to the social security insurance, however likeable the concept of contracting-out, where the first part of the pension system goes to the state pension system and the second half goes to private accounts, may seem to be. The objection to this solution is not fundamental but the debt financing of this operation is refused. If a decrease in pension insurance is to be offset by future higher taxes, then such a decrease is meaningless.

The suggested reform is based on a new "inter-generation contract": the older generation will have somewhat lower relative pensions than the preceding generation and the middle-aged and young generations will limit their consumptions in their productive age (either because of higher taxes or because they will be contributing their savings to private funds). Ultimately, the costs of ageing, which are burdening the pension system, will be distributed among the older, middle-aged and younger generations.

It follows from the calculations of the pension reform task force (www.reformaduchodu.cz) that prolongation of the age of retirement for men and women to 65 years alone would mitigate the implicit debt in the PAYG system by the year 2100 in the amount of $250 \%$ GDP by $100 \%$ GDP. Indexing the pensions according to prices would also reduce the implicit deficit by $100 \%$ GDP by the year 2100 , while retaining the pension/average wage ratio at a fairly favourable level of $35 \%$ by the year 2100 .

This means that through a combination of these two methods, it is possible to eliminate the accumulated deficit of the pension system to 50\% GDP by the year 2100 . This deficit is not insignificant; nevertheless, in the context of other numbers, it is not astronomical. It can be reduced or completely eliminated by gradual decrease of the pension/wage ratio - for example down to $30 \%$. And there is still a safety margin based on the possibility to further increase the age of retirement above 65 years.

Privatisation of the pension system is inspirational but it should not take place at the cost of indebting the future or current generations. Mere transformation of an implicit debt into an explicit one will disconcert investors. In the implementation of a pension reform, it is therefore better to prefer the strategy of budget consolidation (instead of debt financing), which is the only method that can increase private savings and support economic growth. 


\section{Conclusion}

The pension system in many countries has sunk into a grave crisis. Its bankruptcy would be a tragedy, not dissimilar to the one experienced during the Great Depression. Holding a belief that with the existing PAYG system people could live to see similarly high pensions as were the ones of the generation of our parents would be irresponsible. However, it is equally irresponsible to imagine that the funded system will eliminate the inter-generation conflict we are facing.

According to the Aaron's rule, the implementation of a funded system should be more advantageous, if the return on private pension funds is higher than the sum of the population growth rate and the growth rate of average wages. However, the application of this rule in practice is more difficult because there are no zero costs of the transition between the two systems. The costs of demographic ageing will impact the productive and non-productive generations - regardless of the type of the pension system.

At present, the political debate about the pension reform is dominated by approaches, which may be politically in conflict, but they have one thing in common: they address the pension system by means of indebtedness. One part of the political spectrum is too lax as concerns the modifications to the parameters of the PAYG system, consequently plunging the system into a deep deficit. The second part prefers a radical reform, which, however, would also be financed by increasing the state debt.

The article has shown that both solutions hide serious pitfalls. The real reform should be budget-neutral, i.e. it should not generate any new budget deficits - whether explicit or implicit ones. Therefore it should be gradually modifying the parameters of the PAYG system. At present, increasing the age of retirement and decreasing the average pension/wage ratio seems to be an option.

\section{References}

Aaron, H. J. (1966), "The Social Insurance Paradox." Canadian Journal of Economics and Political Science, 32, pp. 371-74.

Andrews, E. S., Rashid, M. (1996), "The Financing of Pension Systems in Central and Eastern Europe. An Overview of Major Trends and their Determinants, 1990-1993." World Bank Technical Paper No. 339.

Baldwin, S., Falkingham, J., eds. (1994), "Social Security and Social Change. New Challenges to the Beveridge Model." New York : Harvester Wheatsheaf.

Bental, B. (1989), "The Old Age Security Hypothesis and Optimal Population Growth." Journal of Population Economics, 1(4), pp. 285-301.

Barr, N. (2000), "Reforming Pensions - Myths Truths, and Policy Choices." Washington, IMF WP No. 139.

Barrientos, A. (1998), "Pension Reform in Latin America." Aldershot-Singapore - Sydney : Ashgate.

Barro, R. J. (1974), "Are Government Bonds Net Wealth?" Journal of Political Economy, 82, pp. $1095-1117$.

Barro, R. (1978), "The Impact of Social Security on Private Savings?"Washington : American Interprise Institute.

Becker, G., Barro, R. (1988), "A Reformulation of Economic Theory of Fertility." Quarterly Journal of Economics, 103, pp. 1-26.

Bezděk, V. (2001), "About One of the Possible Scenarios of the Pension System Reform in the Czech Republic (polemic)" (in Czech). Politická ekonomie, No. 2, pp. 241-250.

Bezděk, V. (2000), "Pension System in General as well as in the Context of the Czech Economy I, II" (in Czech). Praha : ČNB. 
Bonoli, G. (2000), "The Politics of Pension Reform. Institutions and Policy Change in Western Europe." Cambridge : Cambridge University Press.

Breyer, F. (1989), "On the Intergenerational Pareto Efficiency of Pay-As-You-Go Financed Pension Systems." Journal of Institutional and Theoretical Economics, 145, pp. 643-658.

Breyer, F. (1994), "The Political Economy of Intergenerational Redistribution." European Journal of Political Economy, 10, pp. 61-84.

Browning, E. K. (1975), "Why the Social Insurance Budget Is Too Large in a Democracy." Economic Inquiry, 13(3), pp. 373-388.

Buchanan, J. M. (1983), "Social Security Survival - A Public-Choice Perspective." The Cato Journal, 3(2), pp. 339-353.

Bulír, A. (1998), "The Future of the Pension System in the Czech Republic" (in Czech). Finance a úvěrCzech Journal of Economics and Finance, 48(1), pp. 1-5.

Cigno, A. (1993), "Intergenerational Transfers without Altruism." European Journal of Political Economy, 9, pp. 505-518.

Coulter, F., Heady, Ch., Lawson, C., Smith, S. (1997), "Social Security Reform for Economic Transition. The Case of the Czech Republic." Journal of Public Economics, 66(2), pp. 313-326.

Feldstein, M. (1974), "Social Security, Induced Retirement, and Aggregate Capital Accumulation." Journal of Political Economy, 82(5), pp. 905-27.

Feldstein, M. (1996), "The Missing Piece in Policy Analysis - Social Security Reform." American Economic Review - Papers and Proceedings, 86(2), pp. 1-14.

Feldstein, M. (1995), “Would Privatizing Social Security Raise Economic Welfare?" NBER Working Paper 5281, Cambridge, MA.

Fenge, R. (1995), "Pareto-Efficiency of the Pay-As-You-Go Pension System with Intragenerational Fairness." Magdeburg : Otto-von-Guericke-Universität Magdeburg.

Friedman, M. (1999), "Speaking the Truth about Social Security Reform." Briefing Papers, CATO Institut, April.

Gokhale, J., Raffelhüschen, B. (2000), "Population Aging and Fiscal Policy in Europe and the United States." Center for Economic Studies, Working Paper No. 237.

Gramm, P. (1998), "Investment-Based Social Security." Policy Report 220. Dallas : National Center for Policy Analysis.

Holman, R. (2002), "Personal Accounts in Medical and Pension Insurance" (in Czech). Prague : Center for Economics and Politics.

Holman, R. et al.(2005), "Study on the Reforms of Medical and Pension Insurance" (in Czech). Prague : University of Economics.

Holzmann, R. (1997), "Pension Reform in Central and Eastern Europe - Necessity, Approaches, and Open Questions." Europa-Institut Saarbruecken Research Paper 9701.

Chand, S. K., Jaeger, A. (1996), "Aging Populations and Public Pension Schemes." Washington, DC, IMF Occasional Paper No. 147.

Jelínek, T., Schneider, O. (1997), "Pension Reform in the Czech Republic - Billions at Stake" (in Czech). Prague : Civic Institute.

Jensen, E. R. (1990), "An Econometric Analysis of the Old-Age Security Motive for Childbearing." International Economic Review, 31(4), pp. 953-968.

Ježek, M. (2003), "A Microanalysis of Pension Reform - To Switch or Not to Switch in the Czech Republic?" Finance a úvěr - Czech Journal of Economics and Finance, No. 11-12, pp. 510-538.

Klaus, V. (2000), "Notes on the Current Pension System and Its Needed Change" (in Czech). In Economics, Law and Politics, CEP, No. 2/2000, pp. 79-82.

Klimentová, J. (1998), "Reform of Pension Insurance 1989-96 and the Current Problems of the System" (in Czech). Finance a úvěr-Czech Journal of Economics and Finance, 48(1), pp. 23-35.

Kotlikoff, L. J. (1996), "Privatizing Social Security at Home and Abroad." American Economic Review, 86(2), pp. 368-372.

Kreidl, V. (1998), "Pension Reform in the Czech Republic" (in Czech). Finance a úvěr - Czech Journal of Economics and Finance, 48(1), pp. 36-54.

Kreidl, V. (1997),“Pension System Reform” (in Czech). Politická ekonomie, No. 6, pp. 836-861.

Kubíček, J. (2004), "Fund Pension System in Converging Economy" (in Czech). Finance a úvěr Czech Journal of Economics and Finance, 54(11-12), pp. 478-499.

Loužek, M. (2004), "Population Economics" (in Czech). Prague : Center for Economics and Politics. 
Loužek, M. (2006), “Is There Any Sense in Pension Reform with Indebtedness?” (in Czech). Politická ekonomie, No. 2, pp. 247-260.

Mach, P. (2005), "Equal Pension as an Alternative to the Current Pension System" (in Czech). In Holman, pp. 123-139.

Mitchell, O. S., Zeldes, S. P. (1996), "Social Security Privatization - a Structure for Analysis." American Economic Review, 86(2), pp. 363-367.

Mora, M. (2000), "Pension Policy in the Czech Republic (Lessons from a Comparative Study with Hungary and Poland)." Prague Economic Papers, 9(1), pp. 47-70.

Neumann, M. (1986), "Möglichkeiten zur Entlastung der gesetzlichen Renteversicherung durch kapitalbildende Vorsorgemassnahmen. "Tübingen : J. C. B. Mohr.

Peters, W. (1995), "Public Pensions, Family Allowances and Endogenous Demographic Change." Journal of Population Economics, 8, pp. 161-183.

Ribhegge, H. (1999), "The Controversy Between the Pay-As-You-Go System and the Fully Funded System on Old-Age Security." In Müller, K., Ryll, A., Wagener, H. J. eds., Transformation of Social Security - Pensions in Central-Eastern Europe. Heidelberg : Physica, pp. 61-77.

Rutarová, R., Slavík, M. (2005), "Contribution to the Discussion about the Reform of the Pension System" (in Czech). Politická ekonomie, No. 3, pp. 349-368.

Schmidt-Hebbel, H. (1998), "Does Pension Reform Really Spur Productivity, Savings, and Growth?" Working Papers Central Bank of Chile 33.

Schneider, O. (1998), "Dynamic Model of Pension Reform in the Czech Republic" (in Czech). Finance a úvěr - Czech Journal of Economics and Finance, 48(1), pp. 55-65.

Siebert, H., Feldstein, M., eds. (2002), "Social Security Pension Reform in Europe." Chicago : University of Chicago Press.

Sinn, H.-W. (1999), "Pension Reform and Demographic Crisis. Why a Funded System is Needed and Why It Is Not Needed." München, Center for Economic Studies, Working Paper No. 195.

Slavík, M. (2006), "The Czech Pension System and the Perspectives of Its Reform." Prague Economic Papers, 15(3), pp. 214-230.

Valentová, M. (2001), "Old Age Pensions System Reforms in the Czech Republic and Slovenia". Prague Economic Papers, 10(4), pp. 352-364.

Vavrejnová, M., Wörister, K., Belabed, E. (2004), "Pension Reform in the Czech Republic Comparison with Austria." Prague Economic Papers, 13(3), pp. 237-259.

Vittas, D. (1998), "Swiss Chilepur - a Model for Pension Reforms?" (in Czech). Finance a úvěr - Czech Journal of Economics and Finance, 48(1), pp. 76-88.

Večerník, J. (2006), "Changing Social Status of Pensioners and the Prospects of Pension Reform in the Czech Republic". Prague Economic Papers, 15(3), pp. 195-213.

Vostatek, J. (1998), "Pension Reform and Social Security System" (in Czech). Finance a úvěr - Czech Journal of Economics and Finance, 48(1), pp. 66-75.

Weizsäcker, R. K. von (1993), "Bevölkerungsentwicklung, Rentefinanzierung und Einkommensverteilung." Berlin - Heidelberg - New York : Springer.

Weizsäcker, R. K. von (1990), "Population Aging and Social Security - A Politico-Economic Model of State Pension Financing." Public Finance, 45(3), pp. 491-509.

Werding, M. (1998), "The Pay-As-You-Go Mechanism as Human Capital Funding. The "Mackenroth Hypothesis" Revisited." Diskussionsbeiträge Nr. V-7-98, Wirtschaftswissenschaftliche Fakultät der Universität Passau.

Zbořil, R., Kubalčík, J. (2000), "About One of the Possible Scenarios of the Pension System Reform in the Czech Republic" (in Czech). Politická ekonomie, No. 4, pp. 557-568. 